\title{
Visceral leishmaniasis: situation diagnosis from the perspective of disease control in Brazil
}

\begin{abstract}
Leishmaniasis is a group of neglected diseases that are highly prevalent worldwide, mainly in the developing world, and can take on severe forms. They are transmitted to the man by the bite of phlebotomines, existing a range of animal reservoirs, among which the dog is considered the main urban host. In this context, leishmaniasis, mainly the visceral form, has been urbanized in Brazil, reaching large urban centers throughout the country. In addition, recently, new areas previously unaffected started to present autochthonous cases of human visceral leishmaniasis. The expansion of the disease to new areas has demonstrated the failure of the measures recommended by national health agencies and calls for a new control model in which popular awareness and environmental management are priority actions.
\end{abstract}

Keywords: visceral leishmaniasis, control, canine infection, health, population, Brazil

\author{
Volume 6 Issue 2 - 2018
}

\author{
Menezes Júlia Alves,' Confalonieri Ulisses,' \\ Carvalho Gustavo Mayr de Lima, ${ }^{2}$ Andrade- \\ Filho José Dilermando, ${ }^{2}$ Margonari Carina ${ }^{2}$ \\ 'Grupo de Estudos Transdisciplinares em Saúde e Ambiente, \\ Instituto René Rachou, Brasil \\ ${ }^{2}$ Grupo de Estudos em Leishmanioses, Instituto René Rachou, \\ Brasil
}

\begin{abstract}
Correspondence: Júlia Alves Menezes, Instituto René Rachou, Avenida Augusto de Lima, I7I5, Barro Preto, Belo Horizonte, Minas Gerais, Brasil,Tel +55 31 3349-774I,

Email menezes.jalves@gmail.com
\end{abstract}

Received: Febraury 06, 2018 | Published: March 28, 2018

\section{Mini review}

Leishmaniasis is a spectrum of chronic-infectious diseases caused by intracellular protozoa of the genus Leishmania (Kinetoplastida, Trypanosomatidae). In the New World, the eco-epidemiology of the disease is closely related to animal reservoirs as the main source of parasites, being an anthropozoonosis of great importance in public health in Brazil. ${ }^{1,2}$ Visceral Leishmaniasis (VL) is considered the most severe form of the disease, and potentially fatal if untreated. In the country, the etiological agent of this clinical manifestation is Leishmania (Leishmania) infantum and the main vector is Lutzomyia longipalpis. ${ }^{3}$

The Leishmania $s p$. life cycle is complex and involves both vertebrate and invertebrate hosts. There are two developmental stages of the parasite: one is found in the midgut of a variety of sandfly species (female only) - the proliferative forms named promastigotes; while another (amastigotes) are able to live in mammalian host cells. In general terms, the cycle begins when a female sandfly bites an infected host (i.e. humans, dogs) and is infected by the amastigote form present in the host macrophages. The amastigotes then transform into procyclic promastigotes that multiplies into the sandlfy midgut, migrating to the stomodeal valve. After several cell divisions, procyclic promastigotes transforms into metacyclic promastigotes, which is released by sandfly via regurgitation during the next the blood meal. Some known risk factors for visceral leishmaniasis are humidity and accumulated organic matter, absence of basic sanitation and garbage collection, proximity to green areas, domestic or farmed animals near houses (chickens, birds), low education..$^{4-8}$

The first case of the disease in Brazil was identified by Penna in the state of Bahia, Northeast region, in 1934, by viscerotomy for the diagnosis of yellow fever. ${ }^{9-11}$ Later, successive records were made to the same place and other states of the Northeastern Brazil, a region considered endemic for VL until nowadays. ${ }^{10-12}$ The first reports on the disease, still in the $1930 \mathrm{~s}$, pointed to the strictly wild profile of the disease cycle, in which the characteristics of soil, vegetation, climate and landform seemed to favor the occurrence of both sand flies and reservoir animals. ${ }^{12}$ In fact, leishmaniasis remained among wild and domestic animals, as well as sand flies in the tropical areas where the primary hosts were rodents, marsupials, edentates, procionids, ungulates, and primates. ${ }^{13}$ Man was accidentally involved in the transmission cycle when invading the forest environment or colonizing areas near to wild foci, which associated the VL to work factors (e.g. agriculture, livestock, hunting), a profile still observed in the present day. ${ }^{3,14}$ However, at that time, human settlements and the presence of domestic animals were not considered important factors for the spread and risk of the disease, a fact that proved relevant to the epidemiology of VL in Brazil in urban and peri-urban areas from 1980, when it expanded to several regions of the country. ${ }^{15}$

Currently, the disease can be found in all regions of Brazil, including two southern states that, until recently, had never presented autochthonous cases - Santa Catarina in 2017 and Rio Grande do Sul in 2009. ${ }^{16,17}$ The emergence of cases in areas that previously did not register the occurrence of the disease in humans, along with the difficulty in effectively reduce the incidence of VL in the country, has raised questions about the effectiveness of the control measures recommended by the Ministry of Health..$^{18,19}$ These are mainly based on the early diagnosis and treatment of human cases, the reduction of the population of sand flies - Lu. longipalpis is the most important vector in the country - and the culling of infected reservoirs, namely domestic dogs, which are considered the main urban reservoir. ${ }^{20,21}$ However, in view of the difficulty in containing the new cases of VL, the Ministry of Health also adopted environmental management strategies (i.e. cleaning of yards and public public) to control the immature forms of the vector and the treatment of canine positive cases with the Milteforan ${ }^{\circledR}$, a drug recently released in Brazil by the Technical Note $\mathrm{n}^{\circ} 11 / 2016 .{ }^{21,22}$

Until the publication of this technical note, canine treatment in 
Brazil was prohibited when it was based on drugs that were also used for human treatment or that were not released by the Ministry of Agriculture, a measure aimed at preventing the emergence of Leishmania strains resistant to the available medicines. ${ }^{23}$ In the meantime, several treatment protocols were developed in an attempt to avoid canine sacrifice, either by drug association or by individual use - meglumine antimoniate, miltefosine, allopurinol, amphotericin b. ${ }^{24-27}$

However the controversy of "treatment $x$ euthanasia" remains in Brazil. On the one hand, the scientific literature has supported the ineffectiveness of euthanasia in seropositive dogs and pointed out to more successful actions in VL control, whose focus is the combined use of strategies - popular awareness, risk control actions, prophylactic measures such as use of collars and repellents directed to dogs. ${ }^{28-30}$ On the other hand, the technical note regarding the Milteforan ${ }^{\circledR}$ liberation stresses that the choice for treatment is an exclusive option of the owner of the animal, and that this attitude does not constitute a public health measure to control the disease.

Among the factors that have contributed to both the expansion of the VL as to reduce the effectiveness of control measures can be listed

i) The environmental changes of the last decades, mainly characterized by increased deforestation (hydroelectric, mining, urbanization).

ii) The uncontrolled growth of cities.

iii) The migration of people and animals from the endemic regions to the unaffected areas.

iv) The economic exploitation of forested areas, which favored the movement of sand flies and reservoirs to areas close to urban areas.

v) The adaptation of $\mathrm{Lu}$. longipalpis to new niches and food sources (i.e. domestic and synanthropic animals).

vi) Reduction of investments in health and education accompanied by discontinuation of control actions. ${ }^{31-36}$

Another important factor is the adaptability of parasites and vectors to new ecological niches. Studies show, for example, areas of the state of Rio de Janeiro where there are autochthonous cases of VL, but in which the occurrence of the main vector - Lu. longipalpis - is not frequent or is even absent, directing suspicions to other recurrent species in the region, such as Migonemyia migonei. ${ }^{37,38}$ In the state of Mato Grosso, central part of the country, the vector incriminated has been Lutzomyia cruzi, since no human and canine cases occur; $L u$. longipalpis is absent, and $L u$. cruzi has already been found naturally infected by Le. (L.) infantum. ${ }^{39}$

In this scenario, health education emerges as a key piece to adjust control and prevention practices to the reality of population and territories. ${ }^{40}$ Studies have shown that having some knowledge about leishmaniasis can minimize the risk of its occurrence, and factors such as education are associated with the risk of VL involvement, especially in endemic areas. ${ }^{8,41,42}$ However, studies in the country show that the affected populations are unaware of important concepts about the disease, such as transmission, treatment and prevention; and that education and health professionals, whose work is the connection between information and preventive practices, have incipient and fragmented knowledge on VL.42-46 Therefore, it is envisaged as a concrete and necessary possibility the aggregation of scientific community, health professionals, and civil society to subsidize and act effectively in the VL Control Program in Brazil. To this end, supporting the implementation of appropriate actions needs a set of vital information that will enable constructing a clear diagnosis of the current situation (what are the reservoirs? what are the vectors? what do the population know?). Addressing this issue in the field of health, with all its nuances and complexities, involves having to understand the epidemiological and cultural peculiarities that surround the disease in each territory, thus contributing to define the most appropriate techniques that will support the analysis and/or the control of the situation (i.e. educational campaigns, prophylaxis of residences, investment in research). ${ }^{30}$ This allows the information to be collected and organized in a correct way by which the resulting diagnosis makes sense, serving as the basis for implementing consistent and effective actions aimed at improving the health of the population. In this new scenario, there is a need to strengthen the links between science, politics and society, together with the support and engagement of health managers, to disseminate knowledge and promote the health of the population.

\section{Acknowledgements}

None.

\section{Conflict of interest}

The authors declare no conflict of interest.

\section{References}

1. Desjeux P. Leishmaniasis: public health aspects and control. Clin dermatol. 1996;14(5):417-423.

2. Desjeux P. The increase in risk factors for leishmaniasis worldwide. Trans $R$ Soc Trop Med Hyg. 2001;95(3):239-243.

3. Lainson R, Shaw JJ. Epidemiology and ecology of leishmaniasis in LatinAmerica. Nature. 1978;273(5664):595.

4. Moreno EC, Melo MN, Genaro O, et al. Risk factors for Leishmania chagasi infection in an urban area of Minas Gerais State. Rev Soc Bras Med Trop. 2005;38(6):456-63.

5. Alonso F, Giménez Font P, Manchón M, et al. Geographical variation and factors associated to seroprevalence of canine leishmaniosis in an endemic Mediterranean area. Zoonoses and public health. 2010;57(5):318-328.

6. Teles APS, Herrera HM, Ayres FM, et al. Fatores de risco associados a ocorrência da leishmaniose visceral na área urbana do município de Campo Grande. Hygeia: Revista Brasileira de Geografia Médica e da Saúde. 2015;11(21):35.

7. Menezes JA, Ferreira ED, Andrade-Filho JD, et al. An integrated approach using spatial analysis to study the risk factors for Leishmaniasis in area of recent transmission. BioMed research international. 2015. $10 \mathrm{p}$.

8. Menezes JA, Luz TC, Sousa FF, et al. Peridomiciliary risk factors and knowledge concerning visceral leishmaniasis in the population of Formiga, Minas Gerais, Brazil. Rev Bras Epidemiol. 2016;19(2):362-74.

9. Penna HA. Leishmaniose visceral no Brasil. Brasil Médico. 1934;18:940950 .

10. Abad Gómez H. Leishmaniasis Visceral en las Américas. Boletín de la Oficina Sanitaria Panamericana. 1951;30(3):338-340.

11. Sherlock IA. Ecological interactions of visceral leishmaniasis in the state 
of Bahia, Brazil. Memórias do Instituto Oswaldo Cruz. 1996;91(6):671683.

12. Barreto JD. A saúde pública no Brasil. Boletín de la Oficina Sanitaria Panamericana (OSP). 1939;18(10):923-940.

13. Shaw JJ. New World leishmaniasis: the ecology of leishmaniasis and the diversity of leishmanial species in Central and South America. In: Farrel J, editors. World Class Parasites: Leishmania. Boston: Springer; 2002:1131 .

14. Sosa-Estani S, Segura EL, Gomez A, et. al. Leishmaniose cutânea no Norte da Argentina. Fatores de risco identificados num estudo caso-coorte em três municípios de Salta. Rev Soc Bras Med Trop. 2001;34(6):511-517.

15. Costa $\mathrm{CH}$. Urbanization and kala-azar in Brazil: kala-azar in Teresina Recife, Brazil: Workshop research and control of leishmaniasis in Brazil; 1993.

16. Deboni SC, Barbosa M, Ramos RR. Leishmaniose Visceral no Rio Grande do Sul. Vigilância epidemiológica de casos humanos. Boletim Epidemiológico. 2011;13(1):1-3.

17. http://www.simesc.org.br/documentosLeis/documentos. aspx?CategoriaId $=2419$.

18. Costa DN, Codeço CT, Silva MA, et al. Culling dogs in scenarios of imperfect control: realistic impact on the prevalence of canine visceral leishmaniasis. PLoS Negl Trop Dis. 2013;7(8):e2355.

19. Zuben APBV, Donalísio MR. Dificuldades na execução das diretrizes do Programa de Vigilância e Controle da Leishmaniose Visceral em grandes municípios brasileiros. Cad Saúde Pública. 2016;32(6):e00087415.

20. http://www.planalto.gov.br/ccivil_03/decreto/1950-1969/D51838.htm.

21. Ministério da Saúde. Manual de vigilância e controle da leishmaniose visceral. Departamento de Vigilância Epidemiológica. $1^{\text {st }}$ ed. Brasília, 2014; 20 p.

22. http://www.sbmt.org.br/portal/wp-content/uploads/2016/09/nota-tecnica. pdf.

23. http://bvsms.saude.gov.br/bvs/saudelegis/gm/2008/pri1426_11_07_2008. html.

24. Baneth G, Hoffman O, Jaffe CL, et al. A study of the treatment of canine leishmaniasis with allopurinol: parasitological status, infectivity to sandflies, clinical \& serological progression. In Worldleish2 Second World Congress on Leishmaniosis. 2001:20-24.

25. Palatnik-de-Sousa CB, dos Santos WR, Franca-Silva JC, et al. Impact of canine control on the epidemiology of canine and human visceral leishmaniasis in Brazil. Am J Trop Med Hyg. 2001;65(5):510-517.

26. Ribeiro MPVM. Tratamento da LV canina e seu impacto na incidência de LV humana e na prevalência da LV em cães. Uma experiência em Belo Horizonte, Minas Gerais, Brasil. In: Informe Final de la Reunión de Expertos OPS/OMS sobre Leishmaniasis Visceral en las Américas. Organización Panamericana de la Salud, Río de Janeiro, Panaftosa. 2006:104-107.

27. Manna L, Vitale F, Reale S, et al. Study of efficacy of miltefosine and allopurinol in dogs with leishmaniosis. Vet J. 2009;182(3):441-445.

28. Courtenay O, Quinnell RJ, Garcez LM, et al. Infectiousness in a cohort of Brazilian dogs: why culling fails to control visceral leishmaniasis in areas of high transmission. J Infect Dis. 2002;186(9):1314-1320.

29. Costa CHN. How effective is dog culling in controlling zoonotic visceral leishmaniasis? A critical evaluation of the science, politics and ethics behind this public health policy. Rev Soc Bras Med Trop. 2011;44(2):232242 .

30. Machado CJS, Silva EG, Vilani RM. O uso de um instrumento de política de saúde pública controverso: a eutanásia de cães contaminados por leishmaniose no Brasil. Saúde Soc. 2016;25(1):247-258.

31. Gontijo CM, Melo MN. Leishmaniose visceral no Brasil: quadro atual, desafios e perspectivas. Rev bras epidemiol. 2004;7(3):338-349.

32. Barata RA, França-Silva JC, Mayrink W, et. al. Aspectos da ecologia e do comportamento de flebotomíneos em área endêmica de leishmaniose visceral, Minas Gerais. Rev Soc Bras Med Trop. 2005;38(5):421-425.

33. Lainson R, Rangel EF. Lutzomyia longipalpis and the eco-epidemiology of American visceral leishmaniasis, with particular reference to Brazil - A review. Mem Inst Oswaldo Cruz. 2005;100(8):811-827.

34. Saraiva L, Andrade Filho JD, Falcão AL, et. al. Phlebotominae fauna (Diptera: Psychodidae) in an urban district of Belo Horizonte, Brazil, endemic for visceral leishmaniasis: characterization of favored locations as determined by spatial analysis. Acta Trop. 2011;117(2):137-145.

35. Vilela ML, Afonso MMS, Costa SM, et al. Lutzomyia (Lutzomyia) longipalpis: fatores associados ao processo de expansão e urbanização da leishmaniose visceral americana. In: Conceição-Silva F, Alves CR, editors. Leishmanioses do Continente Americano. $1^{\text {st }}$ ed. Rio de Janeiro, Brasil: Fiocruz; 2014:183-192.

36. dos Santos Afonso MM, de Miranda Chaves SA, Magalhães MD, et. al. Ecoepidemiology of American Visceral Leishmaniasis in Tocantins State, Brazil: Factors Associated with the Occurrence and Spreading of the Vector Lutzomyia (Lutzomyia) longipalpis (Lutz \& Neiva, 1912)(Diptera: Psychodidae: Phlebotominae). In: David, Claborn, editors. Epidemiology and Ecology of Leishmaniasis. InTech; 2017.

37. Rangel EF, Souza NA, Wermelinger ED, et al. Flebótomos de Vargem Grande, foco de leishmaniose tegumentar no estado do Rio de Janeiro. Mem Inst Oswaldo Cruz. 1986;81(3):347-349.

38. Souza MB, Marzochi MCA, Carvalho RW, et al. Ausência de Lutzomyia longipalpis em algumas áreas de ocorrência de leishmaniose visceral no município do Rio de Janeiro. Cadernos de Saúde Pública. 2003;19(6):109118 .

39. Missawa NA, Veloso MAE, Maciel GBML, et al. Evidência de transmissão de leishmaniose visceral por Lutzomyia cruzi no município de Jaciara, Estado de Mato Grosso, Brasil. Rev Soc Bras Med Trop. 2011;44(1):76-78.

40. Killick-Kendrick R. Education is key to controlling visceral leishmaniasis. Bulletin of the World Health Organization. 2010;88(1):11-12.

41. Dias JCP. Problemas e possibilidades de participação comunitária no controle das grandes endemias do Brasil. Cadernos de Saúde Pública. 1998;14(Supl 2):19-37.

42. Borges BKA, Silva JA, Haddad JPA, et al. Avaliação do nível de conhecimento e de atitudes preventivas da população sobre a leishmaniose visceral em Belo Horizonte, Minas Gerais, Brasil. Cad Saúde Pública. 2018;24(4):777-784.

43. Gama MEA, Barbosa JS, Pires B, et al. Avaliação do nível de conhecimento que populações residentes em áreas endêmicas têm sobre leishmaniose visceral, estado do Maranhão, Brasil. Cad Saúde Pública. 1998;14:381390 .

44. Margonari C, Menezes JA, Rocha MN, et al. Public knowledge about and detection of canine visceral leishmaniasis in urban Divinópolis, Brazil. $J$ Trop Med. 2012:429586.

45. de França VH, Margonari C, Torres Schall V. Percepção de professores do ensino básico em relação as suas práticas educativas sobre leishmanioses: um estudo em área endêmica de Minas Gerais. Ensaio Pesquisa em Educação em Ciências. 2013;15(3):35-51.

46. Menezes JA, Maia KN, Verne RN, et al. Leishmanioses: o conhecimento dos profissionais de saúde em área endêmica. Revista Brasileira em Promoção da Saúde. 2014;27(2):207-215. 